\title{
1. Introduction to Space Insurance and the Law
}

\section{GOALS}

As we have seen from the numerous high-profile launch failures and accidents that have occurred between 2014 and 2016, space activities are still ultra-hazardous in nature, despite 60+ years of technological development. These activities range from essential to modern life (e.g., telecommunications) to futuristic and forward thinking (e.g. space tourism). In order for these activities to not only continue, but also develop and grow, this inherent risk must be managed. This risk can be managed through policies, laws, and regulations implemented at the State level to balance the interests of the State. The risk can also be managed by purchasing insurance to cover potential losses. The central principle advanced by this book is that insurers are well-poised to provide a meaningful contribution to the governance of space activities, and indeed that they inherently contribute to such governance both by deciding who they will insure and under what terms and conditions they will insure them.

When a private entity seeks to place a satellite in orbit, the two greatest expenses in pursuing this goal are obvious and heavily considered: the cost of the satellite itself, and the cost of the launch. There has been a great deal of discussion and literature regarding the issues of satellite cost, such as the impact export controls have on efficient international development and cooperation, and the need to find less costly launching solutions, such as reusable vehicles and cheaper fuel. What is not often discussed, however, is what is often the third greatest expense for our hypothetical private entity: insurance. In order for the private space sector to innovate and expand, insurance costs must be taken into consideration. An efficient capacity increase in the space insurance industry would benefit not only those private entities seeking insurance, but also the industry itself. Further detail regarding the importance of the insurance market to the space industry can be found in both the History section of this chapter and in Chapter 3: The State of Space Insurance.

Additionally, one means to encourage this industry that has not been fully explored in the literature is management of risk through insurance-based standards, rather than governmentally imposed standards. Thus, the purpose of 
this book is to answer the following questions. Given the reluctance of States to provide sufficient regulations in the space arena, particularly for emerging technologies:

1. From a legal and policy perspective, is there a regulatory void that needs to be filled, at least temporarily?

2. Are insurance companies in a position to be able to fill or partially fill that void?

3. If so, how, and what actions can they undertake to improve their ability to execute that governance function?

These are important questions for a variety of reasons. First, there is the difficulty with the progressive development of the international space law regime; namely, the dormancy of the Moon Agreement and failure to develop further treaty law in its wake, and the lack of clarity surrounding the applicability of soft law instruments (discussed in further detail in Chapter 4). The second factor is the fear of stymying domestic space industries through overregulation that exists at a domestic level, limiting the extent of regulation on which States are willing to take the lead. The third reason is the inherently high-risk nature of space activities, resulting in relatively high costs for space insurance. Of course, this assessment presupposes that society has deemed space activities worthy of the risk they entail generally, and this supposition is reviewed in Chapter 2.

This book is a helpful guide for academics and practitioners in the space, legal, insurance, and political science fields, but most specifically to those involved directly in the space-related or near-space-related arena. A goal of this book is to encourage participants in space activities to think meaningfully about the role insurance has to play in the sustainable development of the industry. If regulators and insurers in particular are conscientious with respect to the role that insurers can and do play in the industry (rather than unaware or uninterested), the outcomes are likely to be improved for all involved. One particular subject area for ongoing conversation is the protection of the space environment from excessive man-made space debris that may threaten the viability of continuing and developing space activities in the future.

\section{HISTORY}

The "space insurance industry" emerged as a separate field of insurance in 1965. Since then, there has been significant growth and evolution of the industry. Communication satellite problems, spacecraft and launch failures, increasing space debris, and cyclical periods of high solar energy all contribute to space insurance being considered a "high risk" field of insurance. The period 
from late 2014 to the present has seen a number of high publicity failures in the space sector that have demonstrated the continuing high risk involved in space activities. The first such failure was the Orbital Sciences resupply rocket meant for the International Space Station (ISS) that exploded during launch. ${ }^{1}$ The second fell a mere few days later on Halloween of that year - the crash of Virgin Galactic's SpaceShipTwo, which tragically and notably resulted in the first fatality from private spaceflight, one of the pilots aboard. ${ }^{2}$ The year 2015 saw an international failure rate of 5.75 percent; five failures of the 87 attempted launches. ${ }^{3}$ Media darling SpaceX has experienced two rocket failures, the first in June of $2015^{4}$ and the second at the beginning of September 2016. ${ }^{5}$ A Russian rocket also bound to resupply the ISS was lost in a late 2016 launch. ${ }^{6}$ In 2017 the international failure rate increased slightly, to 6.7 percent, ${ }^{7}$ which then fluctuated to a remarkably low 2.6 percent in $2018^{8}$ and back up to 4.9 percent in $2019 .{ }^{9}$

These incidents are the growing pains of a technologically difficult activity being carried out by an increasingly diverse set of actors. The increases in the number of private actors in the space industry as well as the rapid development of space laws are indicators of growth in the commercial space sector. As early as 2008 , the insured value of the in-orbit insured satellite fleet alone was $\$ 17.5$

\footnotetext{
1 Mike Wall, "Private Orbital Sciences Rocket Explodes During Launch, NASA Cargo Lost" (28 October 2014) online: Space.com, https://www.space.com/27576 -private-orbital-sciences-rocket-explosion.html.

2 Juliette Garside \& Ian Sample, "Disaster at the Speed of Sound: The Tragedy of SpaceShipTwo's Final Flight” (7 November 2014) online: The Guardian, https://www .theguardian.com/science/2014/nov/07/virgin-galactic-tragedy-revealed-spaceshiptwo -disaster.

32015 Space Launch Statistics (29 December 2015) online: spaceflight101.com, http://spaceflight101.com/2015-space-launch-statistics/.

4 Mike Wall, "SpaceX Rocket Explodes During Cargo Launch to Space Station" (28 June 2015) online: Space.com, http://www.space.com/29789-spacex-rocket-failure -cargo-launch.html.

5 James Dean, "SpaceX Falcon 9 Rocket, Satellite Destroyed in Explosion" (2 September 2016) online: Florida Today, http:/www.floridatoday.com/story/tech/ science/space/spacex/2016/09/01/explosion-reported-spacex-pad/89710076/.

6 Stephen Clark, "Russian Space Station Cargo Freighter Lost on Launch" (1 December 2016) online: Spaceflightnow.com, https://spaceflightnow.com/2016/12/01/ progress-ms04-launch/.

2017 Space Launch Statistics (31 December 2017) online: spaceflight101.com, http://spaceflight101.com/2017-space-launch-statistics/.

82018 Space Launch Report (29 December 2018) online: https://www .spacelaunchreport.com/log2018.html.

92019 Space Launch Report (27 December 2019) online: https://www
} .spacelaunchreport.com/log2019.html. 
billion. ${ }^{10}$ In 2010, of the almost 1,000 operational satellites in orbit, only 175 commercial satellites were insured. ${ }^{11}$ As of 2015, the space insurance market covers approximately 205 satellites orbiting the Earth with a value of approximately \$26 billion. " "In 2018, roughly two-thirds of launched satellites globally carried some form of insurance - a ten-year high for the market." ${ }^{\prime 13}$ For additional context, a single rocket crash in 2019 cost space insurers over $\$ 411$ million dollars. ${ }^{14}$ There has been an ongoing growth in entrepreneurial space activity, particularly in the United States; such companies as Virgin Galactic, SpaceX, Bigelow, Orbital Sciences, Xcor, Golden Spike, and Planetary Resources serve as examples. In 2009, the estimated total investment to the spaceflight industry was US\$1.46 billion. Of this investment, government contributions made up only 15 percent. The standard premium cost for launch insurance ranges from 5 to 20 percent of the satellite's value; with the market expected to settle in this phase at around 10 percent. ${ }^{15}$ This high cost of insurance and relatively low capacity of the market acts as a barrier to entry in the space industry for emerging companies. In an era when motivations for space activities are being re-evaluated, while private companies are encouraged by such programs as the $\mathrm{X}$ Prize to participate in space activities, it is critically important that the insurance industry be ready and able to provide the necessary coverage to support the space industry.

The United States Congress acted in 1988 to deal with the space insurance problem, by requiring cross-waivers of liability in space activities. Before 1988, the commercial space launch sector in the United States was faltering as a result of the unavailability of insurance, even at high premiums, for the

10 Chris Kunstadter, "What Keeps Space Insurers Up At Night ...” (2008) XL Insurance.

11 OECD, "Insurance Market for Space Activities" (2011) The Space Economy at a Glance, OECD Publishing and OECD, "The Space Sector in 2011 and Beyond" (2011) The Space Economy at a Glance, OECD Publishing.

12 Scott Ross, "Risk Management and Insurance Industry Perspective on Cosmic Hazards" in J.N. Pelton \& F. Allahdadi eds, Handbook of Cosmic Hazards and Planetary Defense (Cham, Switzerland: Springer, 2015) at 1096.

13 Lindsay D. Chaney \& Nicholas S. Hirano, "End of an Era? Satellite Insurance Faces Changing Landscape" (November 2019) online: Aerospace Corporation, https:// aerospace.org/sites/default/files/2019-11/Chaney_SatelliteInsurance_11132019.pdf at 4.

14 Carolyn Cohn, Tom Sims, \& Noor Zainab Hussain, "Space Insurance Costs to Rocket After Satellite Crash" (31 July 2019) online: Reuters, https://www.reuters .com/article/us-space-insurance/space-insurance-costs-to-rocket-after-satellite-crash -idUSKCN1UQ1SK.

15 Jeff Foust, "Space Insurance Rates Increasing as Insurers Review their Place in the Market" (14 September 2019) online: SpaceNews, https://spacenews.com/space -insurance-rates-increasing-as-insurers-review-their-place-in-the-market/. 
immense liability faced by launch providers ${ }^{16}$ Though this approach was able to reverse the degradation of the space industry in the United States, it did not solve the problem of the limited availability and expense of insurance. While it rendered the participation in space activities possible without the burden of insurance, it is unquestionable that the availability of reasonably priced, comprehensive insurance would encourage further growth and development.

\section{OVERVIEW}

There are many moving parts in a thorough understanding of space insurance, its legal parameters, and its governance role in the space industry. This book sets out to address as complete a picture as possible of those elements. Chapter 2 of this book will introduce the theories of non-State governance to the insurance industry to establish the extent to which it can or cannot serve a governing or regulatory function for the space industry. First, the chapter takes an analytical view of risk; explaining from a very basic perspective what risk is and why we take risk in space. Insurance is a traditional means of trading and sharing risk, and thus to understand insurance we must understand risk. This chapter then provides context for how insurers have acted as governors by contractually enforcing best practices on industry as a regulatory alternative in other sectors and then applies this understanding to the space industry specifically. While comparisons have previously been made generally between space activities and high-risk sports/recreational activities, one section of this book provides a new approach to this issue. It specifically compares different types of mountain climbing to space activities from the perspective of societal value and perception, to help understand how we take and perceive risks in space. Identifying what risks we are taking in space and why can help to establish, in a later review of the law, what kind of regulatory formula could or should be applied to identify the gaps. The subsequent analysis allows the application of the existing insurance as governance socio-legal theory to the space industry in particular, for which substantial study has not been previously undertaken.

Chapter 3 is the briefest chapter of this book, as it is the contextual chapter that provides background information on the space insurance industry so the reader may understand how the concepts to be critically analyzed apply to this sector. It is necessary background in order to effectively answer research sub-questions two and three. This chapter reviews both the types of insurance currently available to the space industry and also the current capacity of the industry.

16 Martin Marietta Corp. v. INTELSAT (1991) 763 F.Supp. 1327. 
Standard third party space insurance policies, such as those offered by MunichRe (which claims to hold 15-20 percent of global space premium volume) include pre-launch insurance, launch insurance, and in-orbit insurance. ${ }^{17}$ Those companies which articulate their coverage in greater detail include separate items for assembly, integration and test coverage; service interruption, loss of revenue, broadcast events; and "captive cover" (an insurance company created by an entity or group to provide insurance for itself) to assist those companies which self-insure their space risks. ${ }^{18}$ These types of insurance are more geared toward the satellite industry than to new, innovative space activities. Aon, a broker which claims to place over 35 percent of the world's space insurance premium, does not specify which coverage is offered, and instead offers tailor-made solutions. ${ }^{19}$ Indeed, the larger space enterprises are apt to obtain "manuscripted" (individualized) insurance policies that are tailored to their specific needs. These policies are likely, however, to be extremely expensive and difficult to procure. Thus, the lack of standard coverage in the marketplace that can be endorsed to address the needs of particular entrepreneurial endeavors hinders development of such endeavors. The refinement and standardization of satellite-oriented insurance offerings would also contribute to increased insurance capacity at lower premium, allowing additional entrants to the satellite market. Such standards are particularly relevant for those developing countries wishing to develop space capabilities.

Additionally, third party liability insurance is the insurance that provides coverage to third parties not involved in the space activity or contract, and is a particularly important developing area (see Allianz, Star Companies, and Torus for examples), especially given the current legal regime that provides for State liability. ${ }^{20}$ Some companies expressly do not cover such critical aspects of space activities as third party liability and pre-launch activities. ${ }^{21}$ It is important to note that first party liability, dealing with damages to one's own property, and second party liability, dealing with damages to those individuals with whom one contracts (such as passengers) are also important factors in the

\footnotetext{
17 “Market Requirements” Munich RE Space, online: http://www.munichre.com/ en/reinsurance/business/non-life/space/market.aspx.

18 "Space Insurance" Allianz Global Corporate \& Specialty, online: https://www .agcs.allianz.com/solutions/aviation-insurance/space-insurance.html\#tabpar_9562 $1 \mathrm{Ta}$.

19 "International Space Brokers" Aon, online: http://www.aon.com/industry -expertise/space.jsp.

$20 \quad$ See Chapter 4.

21 "Aviation and Space" SwissRe Corporate Solutions, online: http://www.swissre .com/corporate_solutions/industries/aviation_space/.
} 
space insurance market and are in fact essential elements in a comprehensive insurance as governance approach.

This chapter also discusses Lloyd's of London in particular, which started as a maritime insurer, and provides an interesting and highly evolved model for insuring high-risk ventures. The quota-sharing regime that allows risk-sharing among syndicates (and "names") enables the writing of insurance for very large risks, with less risk to the individual underwriting. It also allows those underwriters with particular expertise in an area to take the lead, demonstrating to insurers with less expertise that it is safe to take on a piece of that risk's pie. There is also substantial reinsurance that follows the initial underwriting process. Thus, Lloyd's syndicates serve as a financially viable model with respect to the questions asked by this book.

Chapter 4 analyzes the legal and regulatory context that exists in outer space with regard to space activities and by extension space insurers, identifying and examining conflicts or gaps in the law relevant to the critical question posed by this book. This context consists of laws and regulations that impact the insurance industry generally, and the space insurance industry in particular.

International space law currently consists primarily of the five major United Nations treaties (Outer Space Treaty, Return and Rescue Agreement, Liability Convention, Registration Convention, and Moon Agreement), along with customary international law. ${ }^{22}$ Relevant declarations and guidelines on the one hand ("soft law") and national legislation on the other should also be noted, and are subsequently discussed in this book. The instruments of international space law are critical to an understanding of the role of insurance in the space industry, and thus comprise Chapter 4 of this book. A brief overview is provided here, with an additional overview followed by in-depth analysis of the relevant provisions contained in the chapter itself.

The Outer Space Treaty of 1967, the first and most comprehensive element of binding treaty law in space, assigns responsibility and liability through articles VI and VII for all space activities to the respective State carrying out those activities, even when the activities are carried out by private entities. Article VI, which assigns "international responsibility for national activities in outer

22 Treaty on Principles Governing the Activities of States in the Exploration and Use of Outer Space, including the Moon and Other Celestial Bodies, 27 January 1967, 610 UNTS 205 [Outer Space Treaty]; Agreement on the Rescue of Astronauts and the Return of Objects Launched in Outer Space, 22 April 1968, 672 UNTS 119 [Return and Rescue Agreement]; Convention on International Liability for Damage Caused by Space Objects, 29 March 1972, 961 UNTS 187 [Liability Convention]; Convention on Registration of Objects Launched into Outer Space, 14 January 1975, 1023 UNTS 15 [Registration Convention]; Agreement Governing the Activities of States on the Moon and Other Celestial Bodies, 18 December 1979, 1363 UNTS 3 [Moon Agreement]. 
space ... whether such activities are carried on by governmental agencies or by non-governmental entities, and for assuring that national activities are carried out in conformity with the provisions set forth in the present Treaty" creates a unique responsibility regime in international law. International responsibility for space activities rests solely on States. ${ }^{23}$ Article VII renders States "internationally liable for damage to another State Party to the Treaty or to its natural or juridical persons" by its space objects.

Article III of the Outer Space Treaty explicitly recognizes that principles of international law generally apply to space activities, bringing such documents as the Articles on Responsibility of States for Internationally Wrongful Acts and International Court of Justice decisions into the relevant scope of space law for the purposes of understanding State responsibility. "[B]oth treaty law and general principles of international law on the subject of space law make the two elements of liability and responsibility a means to an end - that of awarding compensation to an aggrieved state or other subject under the law." 24 Thus, these general principles are likely to achieve the same aims even in cases where the Outer Space Treaty or Liability Convention (discussed below) do not apply.

The subsequent Liability Convention further expands the concept of state liability for space activities, assigning absolute liability for "damage caused by its space object on the surface of the Earth or to aircraft in flight" and fault-based liability for damage to a space object of another state or to persons or property on board such a space object. ${ }^{25}$ The Outer Space Treaty and Liability Convention have 110 and 98 ratifications respectively, including most space-faring states, and as such have broad applicability. ${ }^{26}$

Additional requirements are imposed with regard to space activities by the other treaties mentioned above. The Registration Convention, for example, requires States to maintain national registries of space objects and to provide that information to the United Nations. ${ }^{27}$ Under the terms of the Registration Convention, a launching State is required to register a space object. ${ }^{28}$ Given that jurisdiction and control of a space object rests inseparably with the reg-

23 Paul Stephen Dempsey, "Liability for Damage Caused by Space Objects Under International and National Law" (2012) XXXVII Ann Air \& Sp L 333.

24 Ruwantissa Abeyratne, "Synergies and Problems in Outer Space Insurance and Air Transport Insurance" (2003) 30 Transp LJ 189.

25 Liability Convention, supra note 22, arts II-III.

26 Status of International Agreements Relating to Activities in Outer Space as at 1 January 2020, COPUOS, UN Doc A/AC.105/C.2/2020/CRP.7 (2020) at 10.

27 Registration Convention, supra note 22, arts II \& IV.

28 Registration Convention, supra note 22, arts II \& V. 
istering State in accordance with Article VIII of the Outer Space Treaty, the Registration Convention is also intertwined with the liability regime.

Article IX of the Outer Space Treaty requires that States act with "due regard" for the space activities of other States (and, therefore, other States' private enterprises), avoiding "harmful interference" in carrying on space activities. It also specifies that adverse changes to the environment of Earth and harmful contamination of outer space are to be avoided. This article further contributes, albeit weakly, to the liability regime by creating a standard of care owed to other States and a basis for environmental requirements.

As a result of this international law regime, national regulations of many States require private entities to indemnify the State and to carry particular levels of third party liability insurance, including the United Kingdom, United States, France, Ukraine, the Russian Federation, China, Japan, and Australia. ${ }^{29}$ If private enterprises are to continue participating in space activities, there is an obvious need for the availability of insurance for space activities. Current insurance availability is not optimal for the encouragement of this industry, and must be further developed in light both of the legal regime and the unique risks inherent to outer space.

Finally, the principles of non-appropriation and free access play a role in terms of emerging industries that seek to mine or otherwise use and process non-renewable natural resources in space. Article II of the Outer Space Treaty mandates that outer space and celestial bodies are not subject to national appropriation, and there is an inherent regulatory risk present in the uncertainty that this principle creates with regard to resource extraction. Though the Moon Agreement provides guidelines for the establishment of a regime for the extraction and processing of such resources, there has been limited acceptance of this treaty, which has only been ratified by 18 States. $^{30}$

While it is obvious why space law would play an essential role with regard to space insurance, it may not be as obvious that aviation law is potentially implicated as well and is also important for context. The critical issue of the delimitation between air space and outer space is analyzed in Chapter 5 and the state of international liability and safety law with regard to aviation, including the ways that some space activities may be implicated, are explained in Chapter 6. Public international air law is governed primarily by the Chicago Convention on Civil Aviation and by the International Civil Aviation Organization (ICAO), created by that convention. ${ }^{31}$ The international safety standards to which States

29 Paul S. Dempsey, "Liability for Damage Caused by Space Objects Under International and National Law" (2012) XXXVII Ann Air \& Sp L 333.

30 Status of International Agreements, supra note 26.

31 Convention on International Civil Aviation, 7 December 1944, 15 UNTS 295, ICAO Doc 7300/6 [Chicago Convention]. 
and thus airlines adhere are derived from international cooperation through ICAO. Private international air law, mostly covering issues of liability, is handled through a combination of the Warsaw Convention and its Protocols, the Montreal Convention, and the Rome Convention. ${ }^{32}$ While none of these treaties can be said to govern space activities, the status of suborbital activities such as parabolic flight and high altitude ballooning is as of yet unsettled, and thus these treaties provide a safety and liability regime that could be utilized, particularly for suborbital point-to-point ventures, to increase certainty in the space field as they have done for aviation.

Of course, these instruments of air law will only gain relevance for such "space" activities if they are deemed to be, in fact, aviation activities. The lack of surety surrounding the liability regime for suborbital ventures is one reason why the lack of a line of demarcation between air space and outer space is so critical. States (including the US) have formed national policies where necessary regarding the status of certain ventures, creating an unharmonized patchwork of rules and standards. The importance of determining a clear regime applicable to each activity for the purposes of efficient, confident insurance writing cannot be understated.

Chapter 7 of this book delves into the particular space legal and regulatory regime in effect in the United States. Given the advanced nature of national space law in the US, and the plethora of private space entities based there, the US is the primary geographical focus of this book and this American author's research. The impact of US national space law on the procurement of space insurance is likewise addressed. This chapter contributes to the book by identifying and analyzing gaps in the space law regime from a US perspective. The Executive Office of the President has in fact specifically identified gaps in existing space law with regard to private missions beyond Earth's orbit, on-orbit servicing activities, and space resource utilization. ${ }^{33}$ More recently, the Trump administration took a particular interest in space, issuing Space

32 Convention for the Unification of Certain Rules Relating to International Carriage by Air 137 LNTS 11 (1929) [Warsaw Convention]; Montreal Convention for the Unification of Certain Rules for International Carriage by Air, ICAO, 2242 UNTS 309 (1999); Montreal Protocol No 4 to Amend the Convention for the Unification of Certain Rules Relating to International Carriage by Air, Signed at Warsaw on 12 October 1929 as Amended by the Protocol Done at the Hague on 28 September 1955, 25 September 1975, ICAO Doc 9148.

33 John P. Holdren, Executive Office of the President/Office of Science and Technology Policy (4 April 2016) online: WhiteHouse.gov, https://www.whitehouse .gov/sites/default/files/microsites/ostp/csla_report_4-4-16_final.pdf. 
Policy Directives and an April 2020 Executive Order regarding space resource utilization. $^{34}$

By way of a brief overview, in 2010, the body of existing statutory national space law in the US was codified into Title 51 of the US Code. ${ }^{35}$ Title 51; along with the FAA Regulations promulgated under the authority of Title $51,{ }^{36}$ and as codified in the Federal Code of Regulations (FCR); and the FCC Regulations that govern the use of radio frequencies ${ }^{37}$ (essential for space operations), promulgated under the authority of the Communications Act and the Communications Satellite Act, ${ }^{38}$ provide the procedures by which a private US entity wishing to engage in space activities must obtain proper licensing. The Commercial Space Launch Competitiveness Act was signed into law in the US in November of 2015; analysis of that act will be included both in this section and in the relevant section in Chapter 8 regarding space resource utilization, along with analysis of emerging technology areas where gaps exist. A discussion of the relevant space policy directives issued by the Trump administration is also included.

Chapter 7 also addresses three other key areas of national space law in the US, State Spaceflight Liability and Immunity Acts, and export controls. Six US States (Virginia, ${ }^{39}$ Florida, California, Texas, New Mexico, and Oklahoma) have promulgated such Spaceflight Liability and Immunity Acts ${ }^{40}$ which have been preempted from 25 November 2015 through 2025 by the Commercial Space Launch Competitiveness Act, mentioned above. The purpose of these acts is to eliminate liability for participant injuries resulting from the risks of spaceflight activities when all the relevant procedures contained in the acts are

34 US, National Space Council Directives, Office of Space Commerce, https://www .space.commerce.gov/policy/national-space-council-directives/ (2020); US, Executive Order on Encouraging International Support for the Recovery and Use of Space Resources, White House, https://www.whitehouse.gov/presidential-actions/executive -order-encouraging-international-support-recovery-use-space-resources/ (6 April 2020).

35 National and Commercial Space Programs, 51 USC (2010).

3651 USC $\S \S 50901$ et seq.

37 US, Communications Satellite Act art 201(c)(11); Communications Act titles IIII (1934); Telecommunication, 47 CFR $§ \S 25.157-25.158$.

38 Ibid.

39 Spaceflight Liability and Immunity Act, Va H.B. 3184, §8.01-227.8 \& \$8.01-227.9 (2007) [VA Spaceflight Act].

40 Spaceflight Informed Consent Bill, Fla S.B. 2438 (2008) [FL Informed Consent]; Spaceflight Liability and Immunity Act, 5 Ca Civil C tit $7 \S 2210$ (2012) [CA Spaceflight Act]; Limited Liability for Space Flight Activities Act, Tex Civ Prac C tit 4 Ch 100A (2011) [TX Spaceflight Act]; Spaceflight Informed Consent Act, N Mex S.B. 240 (2013) [NM Informed Consent]; Spaceflight Liability and Immunity Act, Okla Stat tit $3 \S 351$ (2013) [OK Spaceflight Act]. 
followed. The importance of these acts is twofold: first, if effective, they would have a significant beneficial effect on reducing insurance costs of ventures which include human spaceflight participants; and second, they set a precedent for managing spaceflight participant liability at the earliest stages of industry development, as these States are the sites of key spaceports. These waivers effectively move liability away from the service providers, and thus incentivize purchase or provision of private insurance in case of loss. Unfortunately, such waivers are not always internationally recognized, and this chapter will explore the issues with implementation of these waivers with regard to international transit.

Export controls, the third essential area of national regulation discussed in Chapter 7, have been a significant burden to the space insurance industry. In the United States, designation on the Commerce Control List (CCL) ${ }^{41}$ or International Traffic in Arms Regulations (ITARs) ${ }^{42}$ list impacts the procedures that must be followed to "export" these technologies, which have historically included satellite and launch technologies. Export, in this case, includes the disclosure of technical data: by oral, visual, or written means, and thus includes information that would need to be provided to insurers for effective underwriting. ${ }^{43}$ As many prominent space insurers are located outside the US (e.g., Lloyd's and MunichRe), difficulty exists in providing sufficient technical data to mollify insurers as to the viability of US space ventures due to export restrictions.

A number of new, innovative applications for space activities have emerged, or soon will. These include space-based solar power (SSP), mining and resource extraction, human spaceflight, suborbital spaceflight, orbital and beyond orbit spaceflight, and the deployment of small cubesats. Special considerations for these new activities are addressed in Chapter 8, which provides approaches to developing an appropriate framework for these technologies. One of the primary concerns with regard to such innovative activities is the unavailability of standardized insurance. Individualized ("manuscripted") policies tend to be expensive both due to the amount of work that goes into producing them and, more importantly, due to the uncertainty of the risks involved. An understanding of the ways in which law and regulations impact these activities will help insurers produce more efficiently priced insurance, and thus may also help new entrants to the space insurance market take on some of these risks. Of course,

41 National Defense Authorization Act for Fiscal Year 2013, US Pub L 112-239.

42 US Department of Commerce \& Federal Aviation Administration, Introduction to US Export Controls for the Commercial Space Industry (2008), online: Commerce Department, http://www.space.commerce.gov/library/reports/2008-10-intro2expo rtcontrols.pdf.

43 Foreign Relations, 22 CFR $\S 120.17$. 
the actuarial concerns with regard to policy pricing are largely beyond the scope of this book. Included in this chapter are recommendations for handling the specialized issues relevant to these industries.

Given that one of the purposes of this book is to produce sound recommendations for the space industry, a discussion of the key parts of an insurance policy is critical to understanding the relevant issues and is provided in Chapter 9 of this book. This chapter heavily relies on common law cases, primarily from the UK, home of Lloyd's, which is discussed in more detail in Chapter 3. The chapter first introduces principles of contract interpretation that apply to insurance policies and compares them to similar treaty interpretation provisions, offering another comparison of how insurance and governance may share forms and similarities. The chapter then reviews the key features of an insurance policy that legal counsel should expect to find and manage in the context of a space insurance policy, as these are quite different than what might be found in a treaty or international agreement. This chapter identifies whether the terms of insurance policies can be used to govern the space industry and what areas may provide particular opportunities for such use or for improvement generally.

Chapter 10 provides an in-depth study of the space debris problem and how insurance can help to solve that problem as a regulatory force. A unique comparative approach is taken, comparing the history and development of steam boiler insurance standards as a regulatory mechanism, as facilitated by the Hartford Steam Boiler Insurance Company (HSB), to approaches that could be taken in the space industry. This chapter provides a specific concrete example to help answer the central question of this book. Doctrinal analysis of space law specifically relevant to the problems discussed in this chapter, namely space debris, facilitates this process.

Additionally, there are areas of insurance coverage that are not included in a "standard" space insurance package that could be leveraged to improve the commercial viability of space activities and prevent disaster in the future. Chapter 10 addresses these types of coverage to provide additional recommendations. Specifically, regulatory insurance, intellectual property insurance, and technology risk appear to be prime areas that would benefit space industries. Regulatory insurance is a type of insurance, commonly offered in the medical field, which covers fines and penalties levied by regulators. This type of insurance could prove valuable to the space industry, with evolving national regulations and the potential that an individual company could be subjected to the regulations of multiple States. Intellectual property insurance protects against allegations of infringement and, depending on the coverage provided, can also protect the intellectual property rights of the company against potential infringers. This type of insurance typically covers copyright, trademark, or patent infringement claims. Given the levels of innovation in the space indus- 
try and regulations regarding technology transfer, this type of insurance could be very beneficial in the space industry, particularly if bundled with regulatory insurance. Cyber insurance covers a range of both first and third party losses, including loss or destruction of data, network damage, system failure, breach of confidentiality, invasion of privacy, and transmission of computer viruses, for example. Privacy breach response insurance is a particularly interesting and rapidly expanding field of insurance that has developed in response to regulations that have been promulgated requiring notification and monitoring when data breaches occur. With the vast quantity of data carried by satellites and the increasing likelihood of attacks on such satellites, it is easy to see the potential relevance of a modified form of this insurance in the space arena.

Chapter 11 provides the arrived upon answers to the questions posed in the introduction, including recommendations for the future. The challenges and opportunities presented by insurer governance are presented, and the conclusion that insurers are well positioned to provide governance as a stop-gap measure ahead of the readiness of government actors to do so is reviewed. "Global risks have the power to confuse the mechanisms of organized irresponsibility and even to open them up for social and political action." 44 In other words, insurance doesn't exist in a vacuum ${ }^{45}$ (but insurance certainly exists in space).

In summation: this book tackles the unique problems of insurance embedded in a high-risk (high technology/low predictability) space environment governed by a treaty regime of State responsibility and liability for private actors.

44 Ulrich Beck, World at Risk (Malden, MA: Polity Press, 2014) [Beck 2014] at 59.

45 Jonathan Simon, "Taking Risks: Extreme Sports and the Embrace of Risk in Advanced Liberal Societies" in Tom Baker \& Jonathan Simon eds, Embracing Risk: The Changing Culture of Insurance and Responsibility (Chicago: University of Chicago Press, 2010) at 171. 